\title{
A NEW SPECIES AND RECONSIDERATIONS IN AESCHYNOMENE SERIES SCOPARIAE (LEGUMINOSAE, PAPILIONOIDEAE) IN MEXICO
}

\author{
Velva E. Rudd \\ Smithsonian Institution, Washington, D.C. 20560, U.S.A. \\ and \\ California State University, Northridge, Ca. 91330, U.S.A.
}

\begin{abstract}
Aeschynomene lyonnetii sp. n., from the state of Guerrero, is described; in addition, two collections possibly representing new, undescribed species are noted; $A e$. pringlei Rose, from the state of Morelos, is reinstated as a good species; Ae. ormocarpoides Rudd, in the state of Oaxaca, is recognized as a Diphysa; Ae. vigil Brandegee, from Baja California Sur, is better placed in series Pleuronerviae rather than in series Scopariae.
\end{abstract}

\section{RESUMEN}

Se describe Aeschynomene lyonnetii sp. n., del estado de Guerrero, taxon afín a Ae. langlassei Micheli ex Rudd, Ae. pringlei Rose y Ae. simulans Rose. Además, se señalan dos colectas (una de Sonora y una de Jalisco) que posiblemente representan especies aún no descritas; se reinstala Ae. pringlei Rose, del estado de Morelos, como especie independiente; Ae. ormocarpoides Rudd, del estado de Oaxaca, se reconoce como planta perteneciente al género Diphysa; Ae. vigil Brandegee, de Baja California Sur, queda mejor ubicada en la serie Pleuronerviae que en la serie Scopariae.

In México several species of shrubby and arborescent Aeschynomene in series Scopariae have been recognized (Rudd, 1955, 1975). Most have limited geographic distribution, in some cases apparently restricted to small areas. Being woody, many plants have succumbed to harvesting for fuel, others to browsing by animals, and some to the advances of "civilization". Because of the difficult terrain many areas have been little collected by botanists, and new taxa are still being found.

Aeschynomene lyonnetii Rudd, sp. nov.

Frutex virgatus; rami novelli puberuli, glabrescentes aetate provecta. Stipulae subdeltoideae infra insertionem non productae, caducae. Folia fere 10-20-foliolata. Foliola nunc oblonga nunc obovato-oblonga, 2-7 m longa, 1.5-3 mm lata, supra glabra, subtus subglabra, apice rotundato, apiculato, basi rotundata, asymmetrica, costa plus minusve in centro. Inflorescentiae axillares vel pseudoterminales, racemosae nonnumquam paniculatae, pauciflorae ad multiflorae. Flores circa $7 \mathrm{~mm}$ longi; calyx campanulatus, circa $3 \mathrm{~mm}$ longus, tubo $2 \mathrm{~mm}$ longo, $1.5 \mathrm{~mm}$ diametro, glabro vel subglabro, lobis subaequalibus, $1 \mathrm{~mm}$ longis, puberulentis vel ciliatis. Legumen 1-3-articulatum, moniliforme, articulis suborbiculatis 5-6 mm longis, 5-6 mm latis, subglabris, ciliatis, vel pubescentibus cum pilis adpressis, stipitibus puberulentis, 5-6 mm longis. 
Virgate shrub to about $3 \mathrm{~m}$ tall; young stems puberulent, glabrescent with age. Stipules subdeltoid, attached at the base, scarious, about $1 \mathrm{~mm}$ long, $0.7 \mathrm{~mm}$ wide at the base, early caducous. Leaves about $10-20$-foliolate, the axis about $1.5-3 \mathrm{~cm}$ long. Leaflets alternate, oblong to obovate, $2-7 \mathrm{~mm}$ long, $1.5-3 \mathrm{~mm}$ wide, glabrous above, subglabrous beneath, rounded at apex, apiculate, the base asymmetrically rounded, the midvein essentially central, the margin entire. Inflorescences axillary or pseudoterminal, racemose, sometimes paniculate, few- to many-flowered; bracts deltoid, attenuate, longitudinally striate, about $5 \mathrm{~mm}$ long, $1 \mathrm{~mm}$ wide, caducous; bracteoles ovate, obtuse to subacute, longitudinally striate, about $1 \mathrm{~mm}$ long and wide, ciliate, otherwise glabrous. Flowers about $7 \mathrm{~mm}$ long on pedicels $1 \mathrm{~mm}$ long or less, elongated to $2 \mathrm{~mm}$ long in fruit; calyx campanulate, about $3 \mathrm{~mm}$ long, the tube $2 \mathrm{~mm}$ long, 1.5 $\mathrm{mm}$ in diameter, glabrous or nearly so, the subequal lobes obtuse except the attenuate vexillar lobe about $1 \mathrm{~mm}$ long, puberulent or ciliate; petals (seen dry only) apparently yellowish on keel and wings, the vexillum purplish or reddish, glabrous except puberulent at apex and along upper midvein, reflexed. Fruit 1-3-articulate, moniliform, the articles suborbiculate, 5-6 mm long and wide, subglabrous, ciliate, or sparsely pubescent with appressed hairs, the stipe 5-6 $\mathrm{mm}$ long, appressed-puberulent.

TYPE: México, Guerrero, Iguala, 16 septiembre 1937, E. Lyonnet 1717 (holotype MEXU no. 278334; isotypes MEXU, US).

Other specimens studied: México, Guerrero, Mpio. Zumpango del Río, "a $7.5 \mathrm{~km}$ al S de Mezcala, alt. $860 \mathrm{~m}$ s.n.m., selva caducifolia, en el suelo somero derivado de calizas de la formación Morelos", septiembre 1970, J. L. Contreras 637(MEXU); "a 12 km al sur de Mezcala, altitud 565 m s.n.m., selva baja caducifolia con Mimosa y Bursera, suelo pedregoso, calizo”, 6 diciembre 1982, L. Rico et al. 449 (MEXU, SFV).

The specimen selected as type bears both flowers and fruit. Aeschynomene lyonnetii with its moniliform fruit and suborbiculate articles appears to be related to the other species with more or less similar fruit, i. e., Ae. langlassei Micheli ex Rudd, Ae. pringlei Rose, and Ae. simulans Rose. This is in contrast to other species in the series Scopariae with semiorbiculate articles with the upper margin essentially straight and the lower rounded, including $A e$. amorphoides (S. Wats.) Rose ex Robins., Ae. hintonii Sandw., Ae. nicaraguensis (Oerst.) Standl., Ae. palmeriRose, Ae. paucifoliolata Micheli, Ae. petraea Robins. and Ae. rosei Morton.

In addition to the species described as new in this paper a collection by F.W. Pennell, no. 19700 , in the state of Sonora, "herb, ridge south of Arroyo Cochico, east of San Bernardo, oak ridge, alt. $800-1000 \mathrm{~m}^{\prime \prime}$ might represent a distinct taxon. It is a flowering specimen and shows some similarity to Ae. simulans Rose from the "low hot coastal plain" of Sinaloa and Nayarit. More material, with fruit, is needed to place it satisfactorily.

Another puzzling collection is that of $R$. McVaugh, no. 23327, from Jalisco, "Mpio. Talpa, ca $22 \mathrm{~km}$ S of Talpa de Allende, ca $1450 \mathrm{~m}$ ". It has been tentatively referred to Ae. petraea var. grandifloraRudd but, as noted by McVaugh (1987, p. 269), it is somewhat different from the type and other collections of that taxon.

After reconsideration of Ae. pringlei Rose, based on a collection by C. G. Pringle, no. 
8709 , in the state of Morelos, "limestone hills near Jojutla, $3000 \mathrm{ft}$ ", earlier placed in synonymy under Ae. petraea var. madrensis (Micheli) Rudd (Rudd, 1953), it now seems better treated as a separate species. In addition to the type collection another, Lundell \& Lundell 10505, from Morelos "on mountainside, km 21 of highway, Cañón de Lobos, Yautepec-Cuernavaca Road", is also referable to Ae. pringlei. A comparable example of apparent endemicity to that area is the recently described Brongniartia vazqueziiO. Dorado from Morelos (Dorado, 1989).

A species described as new, Ae. ormocarpoides Rudd (Rudd, 1975), from the state of Oaxaca, assigned to the section Scopariae, must be deleted from the genus and reassigned. It has been recognized by the discerning Mario Sousa S. as a Diphysa! It is now determined as $D$. spinosa Rydb., or, possibly, a new, closely related taxon.

Aeschynomene vigil Brandegee, from the Cape region of Baja California Sur, was originally placed in series Scopariae where it is somewhat anomalous. Further examination of characters suggests that the relationship is with such species of series Pleuronerviae as Ae. fascicularis Schlecht. \& Cham., Ae. nivea Brandegee, and Ae. compacta Rose.

\section{LITERATURE CITED}

Dorado, O. 1989. Brongniartia vazquezii (Fabaceae: Faboideae) a new species from the State of Morelos, México. Syst. Bot. 14: 20-23.

McVaugh, R. 1987. Flora Novo-Galiciana, Vol. 5. Leguminosae. University of Michigan Press. Ann Arbor. $786 \mathrm{pp}$.

Rudd, V. E. 1955. The American species of Aeschynomene. Contr. U. S. Nat. Herb. 32: 1-172.

Rudd, V. E. 1975. Supplementary studies in Aeschynomene III: series Scopariae in México and Central America. Phytologia 31: 431-434. 